\title{
Growing a population of cultivated cardoon (Cynara cardunculus var. altilis DC) for further selection as a reference energy crop
}

\author{
P.V. Mauri, A. Plaza, M.C. Amorós, J. Ruiz-Fernández, M.D. Curt, M. Sanz a n d J. Fernández
}

\begin{abstract}
A population of cultivated cardoon (Cynara cardunculus var. altilis DC) was grown in Madrid (Spain) as a reference crop to select outstanding individuals for energy applications. The work was carried out within the frame of the Spanish funded projects PROBIOCOM (INIA) and FP13-ENER. Seeds for this work were produced by one of the partners of PROBIOCOM - the Agro-Energy Group of UPM - and came from a clonal crop (in vitro propagated plants) previously grown in Madrid. IMIDRA, as Head of that Project, established the reference crop according to the protocol for cardoon energy crop and was responsible for the crop. Seeds were sown in seed trays and once the plants had true leaves they were transplanted into the field. Collection of field data involved 449 individuals at the rosette stage and the dataset comprised the measurement of plant height, rosette diameter and leaf length; leaf type was determined as well. Individuals exhibiting larger leaf size were selected and categorized into two categories: undivided-like leaf blade (16 individuals) and pinnately lobed leaf blade (12 individuals). For these individuals, leaf fresh weight, number of leaves and leaf length of previously selected leaves were determined. Furthermore, three measurements were performed with a SPAD chlorophyll meter and the Munsell color chart. Morphological features were taken according CPVO-OCVV and UPOV protocols. Most plants exhibited pinnately leaves which generally resulted in larger sizes than the undivided-like leaf plants. Results suggested that the morphological plant type could be used as a preliminary selection criterion of $C$. cardunculus for biomass production; however, further studies are needed at harvest time to confirm this trend.
\end{abstract}

Keywords: cultivated cardoon, biomass, dry matter, energy crop

\section{INTRODUCTION}

Cynara cardunculus var. altilis, commonly known as cardoon, is an herbaceous species of the Asteraceae family (Compositae) that grows as a wild plant in the Mediterranean region. In the context of energy crops, it is generally known as Cynara. Nowadays, several biomass feedstocks can be produced for energy in Europe. However, one of the most promising sources of biomass are lignocellulosic crops - like cardoon - that can be used for the production of heat and electricity by means of direct combustion or the production of biofuel and biogas from pyrolysis and gasification, which are already mature technologies (Angelini et al., 2009). Characteristics that support the energy applications of this crop are the relatively low crop inputs, high biomass potential, low moisture content at harvest time and high calorific value of the crop produce.

Energy crops cultivation aims to maximize biomass feedstock obtained per unit of area, minimize production inputs, and avoid land competition with food crops (Lag-Brotons et al., 2015). In addition, environmental co-benefits can be achieved through the sustainable cultivation of energy crops, such as the protection of soil, the increase in terrestrial carbon sinks and reservoirs and the reduction of greenhouse gases emissions (Sims et al., 2006). 
Due to that, agro-systems dedicated to the production of bioenergy have gained importance. Cardoon, a potentially high biomass plant, has been studied as an energy crop in Mediterranean environments since the decade of 1980 (European Project EN3B-0065-E, 1986-88, www.cordis.europa.eu/project/rcn/13084_en.html;Foti et al., 1999; Piscioneri et al., 2000; Fernández et al., 2006; Fernández, 2009). In the research by Gominho et al. (2011) high plant variation was found, showing that crop performance could be improved through plant breeding. Testing some cultivation techniques, Ierna et al. (2012) also found great variability in cardoon. With a view to the promotion of Cynara cardunculus as a renewable source of energy in European agricultural systems and motivated by the previous considerations, we conducted an investigation on the variability of an ad hoc population of cardoon.

The aim of this study was the characterization of a population of cultivated cardoon grown as a reference crop in Alcalá de Henares (province of Madrid, Spain) in order to select outstanding individuals for energy applications. Seeds came from a clonal crop (in vitro propagated plants) grown at the Technical University of Madrid. Collection of field data involved 449 individuals at the rosette stage selected from the reference crop to develop a comprehensive data set.

\section{MATERIALS AND METHODS}

\section{Site and climate description}

A 2-year field experiment was conducted from 2014 to 2015 at 'El Encín' farm of IMIDRA (InstitutoMadrileño de Investigación y Desarrollo Rural, Agrario y Alimentario) at latitude $40^{\circ} 31^{\prime} 12^{\prime \prime} \mathrm{N}$, longitude $3^{\circ} 18^{\prime} 13^{\prime \prime} \mathrm{W}$, altitude $603 \mathrm{~m}$ a.s.l., where a $3500 \mathrm{~m}^{2}$ conservation and production field of cultivated cardoon was developed.

'El Encín' is an experimental farm of the Autonomous Community of Madrid (Spain), sited in the municipality of Alcalá de Henares. Soils are generally Alfisols and Entisols (USDA soil taxonomy) with a wide range of textures (from sandy to clay) and often with presence of limestone. The climate is Xeric Mediterranean, sub-type Mild Meso-Mediterranean although it is commonly described as continental-Mediterranean. Based on historical records (19572000), the average year at El Encín farm is as follows: $13.4^{\circ} \mathrm{C}$ annual mean temperature, $60 \%$ relative humidity, $1.8 \mathrm{~m} \mathrm{~s}^{-1}$ wind speed, $308.9 \mathrm{cal} \mathrm{cm}^{-2}$ day-1 global radiation, $429.7 \mathrm{~mm}$ year-1 precipitation and $744.9 \mathrm{~mm}_{\text {year }}^{-1}$ ETP (Thorntwaite) (Mauri, 2000).

\section{Soil preparation}

Soil properties were quite homogeneous across the field, as seen in Table 1 . The soil was basic, calcareous nature, no saline, with low $\mathrm{N}$ content, medium contents in $\mathrm{P}$ and $\mathrm{K}$, and loam to loam-clay texture. Soil preparation was made in early May 2014, and consisted of chisel ploughing at $60 \mathrm{~cm}$ depth followed by two harrowing passes.

\section{Field crop evaluation}

The crop was grown from achenes (henceforth, 'seeds') of $C$. cardunculus. Seeds came from a clonal crop (in vitro propagated plants) grown in Madrid (Spain) by the Agro-energy Group of the Technical University of Madrid (UPM). Germination test in petri plates resulted in 85\%. Seeds were sown in March 2014 in forestry trays with 35 cells of 200 cc capacity, using one seed per cell. They were transplanted into the field once they exhibited true leaves, keeping $150 \mathrm{~cm}$ distance between plants. A total of 506 plants were transplanted on July 30,2014 , coinciding with a severe summer drought. Due to that, irrigation was needed to help the establishment of the crop. On the whole, taking aside borders and plant failures, the number of individuals considered for data set collection was 449.

Field data collection began in the third week of December and the measurements of leaf parameters and the destructive samplings were finished by the second week of January 2015. Field data were taken over449 individuals at the rosette stage and they comprised the identification of the morphological plant type and the measurements of plant height, rosette diameter and leaf length and the evaluation of leaf lobe intensity. 
Table 1. Mean results of soil analysis and coefficients of variation (cv) in percentage.

\begin{tabular}{lcc}
\hline & Pooled mean & cv (\%) \\
\hline $\mathrm{pH}$ & 8.1 & 1.5 \\
$\mathrm{EC}\left(\mathrm{dS} \mathrm{m}^{-1}\right)$ & 0.3 & 29.9 \\
$\mathrm{CO} 3=(\%)$ & 1.1 & 49.8 \\
$\mathrm{~N}(\%)$ & 0.1 & 6.0 \\
$\mathrm{OM}(\%)$ & 1.2 & 11.0 \\
$\mathrm{P}\left(\mathrm{mg} \mathrm{kg}^{-1}\right)$ & 12.8 & 17.7 \\
$\mathrm{Ca}\left(\mathrm{mg} \mathrm{kg}^{-1}\right)$ & 1897.3 & 13.0 \\
$\mathrm{Mg}\left(\mathrm{mg} \mathrm{kg}^{-1}\right)$ & 370.3 & 31.7 \\
$\mathrm{Na}\left(\mathrm{mg} \mathrm{kg}^{-1}\right)$ & 61.4 & 42.1 \\
$\mathrm{~K}\left(\mathrm{mg} \mathrm{kg}^{-1}\right)$ & 141.0 & 23.3 \\
$\mathrm{Clay}(\%)$ & 36.1 & 8.6 \\
Silt $(\%)$ & 29.4 & 14.9 \\
Sand $(\%)$ & 34.5 & 5.4 \\
\hline
\end{tabular}

Individuals exhibiting larger leaf size were selected for a further evaluation, divided in two morphological category: undivided-like leaf blade and pinnately lobed leaf blade individuals. They were cut down at $\pm 5 \mathrm{~cm}$ from the ground in order not to affect the basal plant part or stump and to assure the plant re-growth. Evaluation of each individual comprised: leaf fresh weight, number of leaves and leaf length of previously selected leaves; measurements with a SPAD chlorophyll meter and Munsell-chart colour were taken as well. Determinations were performed in triplicate. Besides, the protocols of the CPVO-CPVO (2013) and UPOV (2001) were followed for the characteristics: CPVO-CPVO (2013) 1, 2, 3, 5, 7; UPOV (2001) 8, 10, 11, 12, 14, 17, 18, 19.

\section{Data analysis}

All variables were submitted to ANOVA analysis. Significantly different means were separated at 0.05 and 0.01 probability level by the Least Significant Difference (LSD) test. Mean values, standard deviations and standard errors of untransformed data are reported in this work. Statistical analyses were calculated by using SPSS software (v. 21.0; Armonk, NY; IBM Corp).

\section{RESULTS AND DISCUSSION}

Results of the field data taken in 449 plants are shown in Table 2. Most plants (75\%) exhibited pinnately-lobed leaves and resulted in larger sizes than the undivided-like leaf type plants. Thus, the mean rosette diameter $(134.5 \mathrm{vs} .103 .8 \mathrm{~cm})$ and the leaf length $(120.6$ vs $98.6 \mathrm{~cm}$ ) of P-type individuals (pinnately lobed leaf blade) were larger than for the E-type ones (undivided-like leaf blade).

The number of individuals selected for further evaluation was 28; 16 exhibited pinnately-lobed leaf blades and 12 undivided-like leaf blades. Results of fresh weight, dry weight and leaf length (Table 3) were significantly higher for P-type plants than for E-type plants. Thorns were more abundant in leaves of the P-type (pinnately lobed blade) than in the E-type (undivided-like leaf blade). The colour value was 7.5GY 4/4 for both types. No significant differences were found between morphological types for the number of leaves per plant and the chlorophyll content (Table 3), and for the parameters identified with the code numbers 4.4, 4.9, 4.11 and 4.12 shown in Table 4. 
Table 2. Mean results of the variables studied: Dataset 1. Morphological types: E, undividedlike leaf blade; P, pinnately lobed leaf blade.

\begin{tabular}{lccccrc}
\hline Type & $\begin{array}{c}\text { Number } \\
\text { of plants }\end{array}$ & 1.1 Leaf type & $\begin{array}{c}\text { 1.2 Plant: } \\
\text { height }(\mathbf{c m})\end{array}$ & $\begin{array}{c}\text { 1.3 Plant: } \\
\text { diameter }(\mathbf{c m})\end{array}$ & $\begin{array}{c}\text { 1.4 Plant: } \\
\text { length leaf }(\mathbf{c m})\end{array}$ & $\begin{array}{c}\text { 1.5 Leaf: } \\
\text { intensity of lobing }\end{array}$ \\
\hline $\mathrm{E}$ & 114 & $25 \%$ & $70.38( \pm 5.65)^{* *}$ & $103.79( \pm 9.96)^{* *}$ & $98.57( \pm 7.30)^{* *}$ & 3 \\
$\mathrm{P}$ & 335 & $75 \%$ & $78.03( \pm 5.18)^{* *}$ & $134.48( \pm 12.36)^{* *}$ & $120.62( \pm 7.74)^{* *}$ & 5 \\
\hline
\end{tabular}

Table 3. Mean results of the variables studied: Dataset 2 and 3. Morphological types: E, undivided-like leaf blade; P, pinnately lobed leaf blade.

\begin{tabular}{lccccccc}
\hline Type & $\begin{array}{c}\text { 2.1 Plant: } \\
\text { fresh weight } \\
\text { (kg) }\end{array}$ & $\begin{array}{c}\text { 2.1 Plant: } \\
\text { dry weight } \\
(\mathbf{k g})\end{array}$ & $\begin{array}{c}\text { 2.2 Plant: } \\
\text { number of } \\
\text { leaves }\end{array}$ & $\begin{array}{c}\text { 2.3 Leaf: } \\
\text { length leaf } \\
\text { selected (cm) }\end{array}$ & $\begin{array}{c}\text { 2.4 Lobe: } \\
\text { thorns at } \\
\text { lobe base }\end{array}$ & $\begin{array}{c}\text { 3.1 Leaf: } \\
\text { chlorophyll } \\
\text { content }\end{array}$ & $\begin{array}{c}\text { 3.2 Leaf blade: } \\
\text { colour }\end{array}$ \\
\hline $\mathrm{E}$ & 4.91 & 0.56 & 14.88 & 139.45 & $8.33 \%$ & 50.48 & $7 \mathrm{GY} 4 / 4$ \\
& $( \pm 0.54)^{* *}$ & $( \pm 0.06)^{* *}$ & $( \pm 0.97)^{\text {ns }}$ & $( \pm 3.33)^{* *}$ & & $( \pm 1.40)^{\text {ns }}$ & \\
$\mathrm{P}$ & 10.50 & 1.01 & 17.58 & 170.22 & $93.75 \%$ & 53.50 & $7 \mathrm{GY} 4 / 4$ \\
& $( \pm 0.75)^{* *}$ & $( \pm 0.07)^{* *}$ & $( \pm 3.45)^{\mathrm{ns}}$ & $( \pm 10.31)^{* *}$ & & $( \pm 1.42)^{\text {ns }}$ & \\
\hline
\end{tabular}

Table 4. Mean results of the variables studied: Dataset 4. Morphological types: E, undividedlike leaf blade; P, pinnately lobed leaf blade.

\begin{tabular}{|c|c|c|c|c|c|c|}
\hline Type & $\begin{array}{l}4.1 \text { Leaf: } \\
\text { length of } \\
\text { leaf blade } \\
(\mathrm{cm})\end{array}$ & $\begin{array}{l}4.2 \text { Leaf blade: } \\
\text { maximum } \\
\text { width } \\
(\mathrm{cm})\end{array}$ & $\begin{array}{l}4.3 \text { Leaf blade: } \\
\text { maximum width } \\
\text { position } \\
\text { (cm) }\end{array}$ & $\begin{array}{l}4.4 \text { Leaf: } \\
\text { number of } \\
\text { lobes }\end{array}$ & $\begin{array}{l}4.5 \text { Leaf: } \\
\text { number of } \\
\text { longest lobe }\end{array}$ & $\begin{array}{l}4.6 \text { Leaf: } \\
\text { length of } \\
\text { longest lobe } \\
\text { (cm) }\end{array}$ \\
\hline$E$ & $\begin{array}{c}114.00 \\
( \pm 3.03)^{\star *}\end{array}$ & $\begin{array}{c}51.75 \\
( \pm 2.32)^{\star *}\end{array}$ & $\begin{array}{c}49.94 \\
( \pm 2.22)^{n s}\end{array}$ & $\begin{array}{c}25.88 \\
( \pm 1.02)^{n s}\end{array}$ & $\begin{array}{c}9.06 \\
( \pm 0.36)^{* *}\end{array}$ & $\begin{array}{c}33.50 \\
( \pm 1.25)^{\star *}\end{array}$ \\
\hline$P$ & $\begin{array}{c}137.46 \\
( \pm 2.63)^{* *}\end{array}$ & $\begin{array}{c}78.00 \\
( \pm 2.41)^{* *}\end{array}$ & $\begin{array}{c}49.08 \\
( \pm 3.01)^{\text {ns }}\end{array}$ & $\begin{array}{c}26.17 \\
( \pm 0.67)^{\text {ns }}\end{array}$ & $\begin{array}{c}7.33 \\
( \pm 0.28)^{* *}\end{array}$ & $\begin{array}{c}43.42 \\
( \pm 0.51)^{* *}\end{array}$ \\
\hline Type & $\begin{array}{l}4.7 \text { Leaf: } \\
\text { width of } \\
\text { longest lobe } \\
(\mathrm{cm})\end{array}$ & $\begin{array}{l}4.8 \text { Leaf: } \\
\text { number of } \\
\text { basal lobes }\end{array}$ & $\begin{array}{l}4.9 \text { Leaf: } \\
\text { length with } \\
\text { basal lobes } \\
(\mathrm{cm})\end{array}$ & $\begin{array}{l}4.10 \text { Union } \\
\text { basal lobes }\end{array}$ & $\begin{array}{l}4.11 \text { Lobe: } \\
\text { Total number of } \\
\text { secondary } \\
\text { lobes }\end{array}$ & $\begin{array}{l}4.12 \text { Lobe: } \\
\text { number of } \\
\text { secondary lobes } \\
\text { on the side closest } \\
\text { of the leaf base }\end{array}$ \\
\hline$E$ & $\begin{array}{c}18.88 \\
( \pm 0.71)^{* *}\end{array}$ & $\begin{array}{c}5.75 \\
( \pm 0.40)^{* *}\end{array}$ & $\begin{array}{c}13.20 \\
( \pm 1.13)^{n s}\end{array}$ & $93.75 \%$ & $\begin{array}{c}8.44 \\
( \pm 0.39)^{\mathrm{ns}}\end{array}$ & $\begin{array}{c}4.56 \\
( \pm 0.24)^{\mathrm{ns}}\end{array}$ \\
\hline P & $\begin{array}{c}24.46 \\
( \pm 1.07)^{* *}\end{array}$ & $\begin{array}{c}8.08 \\
( \pm 0.69)^{* *}\end{array}$ & $\begin{array}{c}14.83 \\
( \pm 0.67)^{\mathrm{ns}}\end{array}$ & $8.33 \%$ & $\begin{array}{c}8.83 \\
( \pm 0.41)^{\mathrm{ns}}\end{array}$ & $\begin{array}{c}5.17 \\
( \pm 0.21)^{\mathrm{ns}}\end{array}$ \\
\hline
\end{tabular}

Data recorded in this work comprised parameters of agronomic value and descriptive parameters of both two types of plants (P- and E-types). Parameters that can be considered of agronomic value are 1.2, 1.3, 1.4 in Table 1; 2.1, 2.3 in Table 3 and 5.1, 5.2, 5.3, 5.4 and 5.5, in Table 5. On the whole, results of these parameters suggested that P-type plants could be potentially superior to E-type plants from the agronomical side, with higher biomass weight (Table 2) and higher leaf and midrib sizes (Table 5).

Evidence has been provided in this work that the morphological plant type could be used as a preliminary selection criterion of $C$. cardunculus for biomass production followed by criteria based on agronomic production parameters, which should be also determined at harvest time. Other variables like flowering time, flowering uniformity and seed dehiscence, generally included in what it is called agronomic performance of cardoon, should be taken into account if the separate harvest of seeds were wanted. Further research efforts are needed to develop energy cultivars of cardoon as well as to improve the quality of cardoon biomass. 
Table 5. Mean results of the variables studied: Dataset 5. Morphological types: E, undividedlike leaf blade; P, pinnately lobed leaf blade.

\begin{tabular}{|c|c|c|c|c|}
\hline Type & $\begin{array}{l}5.1 \text { Midrib: } \\
\text { length from base } \\
\text { to } 2 \mathrm{~cm} \text { width } \\
\text { (cm) }\end{array}$ & $\begin{array}{c}5.2 \text { Midrib: } \\
\text { Width at } \\
5 \mathrm{~cm} \text { from base } \\
(\mathrm{cm})\end{array}$ & $\begin{array}{c}5.2 \text { Midrib: } \\
\text { width at } \\
35 \mathrm{~cm} \text { from base } \\
\text { (cm) }\end{array}$ & $\begin{array}{c}5.3 \text { Midrib: } \\
\text { thickness at } \\
5 \mathrm{~cm} \text { from base } \\
(\mathrm{cm})\end{array}$ \\
\hline$E$ & $57.44( \pm 1.66)^{* *}$ & $4.39( \pm 0.31)^{\star}$ & $3.68( \pm 0.21)^{\text {ns }}$ & $13.71( \pm 1.01)^{*}$ \\
\hline P & $63.75( \pm 1.30)^{* *}$ & $5.60( \pm 0.32)^{*}$ & $4.18( \pm 0.19)^{\text {ns }}$ & $16.53( \pm 0.88)^{*}$ \\
\hline Type & $\begin{array}{c}5.3 \text { Midrib: } \\
\text { thickness at } \\
35 \mathrm{~cm} \text { from base } \\
\text { (cm) }\end{array}$ & $\begin{array}{l}5.4 \text { Midrib: } \\
\text { Profile of inner side at } \\
5 \mathrm{~cm} \text { from base } \\
\text { (cm) }\end{array}$ & $\begin{array}{l}5.5 \text { Midrib: } \\
\text { length free } \\
\text { of leaflets } \\
\text { (cm) }\end{array}$ & \\
\hline$E$ & $16.83( \pm 1.51)^{*}$ & $1.43( \pm 0.17)^{* *}$ & $12.39( \pm 1.41)^{* *}$ & \\
\hline P & $22.83( \pm 1.31)^{*}$ & $2.18( \pm 0.13)^{* *}$ & $17.93( \pm 1.04)^{* *}$ & \\
\hline
\end{tabular}

\section{ACKNOWLEDGEMENTS}

-IMIDRA; Project FP13-ENER.

- Unión Europea. FEADER. Europa invierte en zonas rurales.

- Ministry of Science and Innovation and National Institute for Agricultural Research (INIA) of Spain; Project PROBIOCOM. RTA2012-00082-C02-01. Co-funded by the European Regional Development Fund (FEDER).

\section{Literature cited}

Angelini, G.A., Ceccarini, L., Nassi o Di Nasso, N., and Bonari, E. (2009). Long-term evaluation of biomass production and quality of two cardoon (Cynara cardunculus L.) cultivars for energy use. Biomass Bioenergy 33 (5), 810-816 http://dx.doi.org/10.1016/j.biombioe.2008.12.004.

CPVO. (2013). Protocol for Test Distinctness, Uniformity and Stability. Cynara cardunculus: Artichoke, Cardoon. CPVO-TP 184 (2), pp.39.

Fernández, J. (2009). El Cultivo de Cardo (Cynara cardunculus L.) para Producción de Biomasa, Núm 2130 HD. ISBN 978-84-491-0890-7 (Ministerio de Medio Ambiente y Medio Rural y Marino), pp.44.

Fernández, J., Curt, M.D., and Aguado, P.L. (2006). Industrial applications of Cynara cardunculus L. for energy and other uses. Ind. Crops Prod. 24 (3), 222-229 http://dx.doi.org/10.1016/j.indcrop.2006.06.010.

Foti, S., Mauromicale, G., Raccuia, S.A., Fallico, B., Fanella, F., and Maccarone, E. (1999). Possible alternative utilization of Cynara spp. Ind. Crops Prod. 10 (3), 219-228 http://dx.doi.org/10.1016/S0926-6690(99)00026-6.

Gominho, J., Lourenço, A., Palma, P., Lourenço, M.E., Curt, M.D., Fernández, J., and Pereira, H. (2011). Large scale cultivation of Cynara cardunculus L. for biomass production. A case study. Ind. Crops Prod. 33 (1), 1-6 http://dx.doi.org/10.1016/j.indcrop.2010.09.011.

Ierna, A., Mauro, R.P., and Mauromicale, G. (2012). Biomass, grain and energy yield in Cynara cardunculus L. as affected by fertilization, genotype and harvest time. Biomass Bioenergy 36, 404-410 http://dx.doi.org/10.1016/ j.biombioe.2011.11.013.

Lag-Brotons, A.J., Gómez, I., and Navarro-Pedreño, J. (2015). Sewage sludge use in bionergy production. A case study of its effects on soil properties under Cynara cardunculus L. cultivation. Span. J. Agric. Res. 13 (1), e11e1101 http://dx.doi.org/10.5424/sjar/2015131-6145.

Mauri, P.V. Coord. (2000). “El Encín”. Clima, Suelo y Vegetación (Consejería de Medio Ambiente. Comunidad de Madrid). ISBN 84-451-1865-X.

Piscioneri, I., Sharma, N., Baviello, G., and Orlandini, S. (2000). Promising industrial energy crop, Cynara.cardunculus: a potential source for biomass production and alternative energy. Energy Convers. Manage. 41 (10), 1091-1105 http://dx.doi.org/10.1016/S0196-8904(99)00135-1.

Sims, R.H., Hastings, A., Schlamadinger, B., Taylor, G., and Smith, P. (2006). Energy crops: current status and future prospects. Glob. Change Biol. 12 (11), 2054-2076 http://dx.doi.org/10.1111/j.1365-2486.2006.01163.x.

UPOV. (2001). Directrices para la Ejecución del Examen de la Distinción, de la Homogeneidad y la Estabilidad. Alcachofa (Cynara.scolymus L.). TG/184/3, pp.26. 